\title{
Refleksi Ketidakadilan Gender dalam Novel Perempuan Berkalung Sorban: Perspektif Gender dan Feminisme
}

\author{
Maria Botifar ${ }^{1}$, Heny Friantary ${ }^{2}$ \\ ${ }^{1}$ IAIN Curup, Bengkulu, Indonesia \\ ${ }^{2}$ IAIN Bengkulu, Bengkulu, Indonesia \\ ${ }^{1}$ mariabotifar@yahoo.co.id, ${ }^{2}$ henyfriantary30@gmail.com
}

Abstract: Gender injustice in the novel entitled "Perempuan Berkalung Sorban" is clearly illustrated in every stage of physical and mental events, verbal and nonverbal communication between characters, a cause-and-effect relationship that makes characters experience a change in destiny, and the movement for change made by characters in changing the fate of life. The purpose of this article is to describe gender injustice in the novel through the perspective of gender and feminism. This novel analysis uses a qualitative approach with a descriptive analysis method. The results show that gender inequality falls in three circles, namely (1) the patriarchal circle of power that governs women from all sides, (2) the stigma circle that views women as the weak so that access to equality does not function, and (3) the patriarchal circle that is the basis for controlling, oppressing and exploiting women in the public and private sphere. For this reason, the attitude of feminism in this novel is illustrated in the behavior of the characters as follows: a) the formation of women's self-concept, b) women's independence, c) the struggle for freedom over self-determination.

Keywords: gender, novel, perempuan berkalung sorban, feminism

Abstrak: Ketidakadilan gender dalam novel Perempuan Berkalung Sorban tergambar jelas dalam setiap tahapan peristiwa fisik dan batin, komunikasi verbal dan nonverbal antar pelaku, hubungan sebab-akibat yang mengharuskan tokoh mengalami perubahan nasib serta gerakan perubahan yang dilakukan tokoh dalam mengubah nasib hidupnya. Tujuan artikel ini adalah memaparkan ketidakadilan gender dalam novel melalui perspektif gender dan feminisme. Analisis novel ini menggunakan pendekatan kualitatif dengan metode deskripsi analisis. Hasil penelitian menunjukkan ketidakadilan gender berada dalam tiga lingkaran, yaitu (1) lingkaran kekuasaan dari garis patriarki yang mengatur perempuan dari berbagai sisi, (2) lingkaran anggapan yang memandang perempuan kaum yang lemah sehingga berbagai akses untuk memperoleh kesetaraan tidak berfungsi, dan (3) lingkaran patriarki yang menjadi dasar untuk mengontrol, menindas dan mengeksploitasi perempuan di ranah publik dan privat. Untuk itu, sikap feminisme dalam novel ini tergambar dalam perilaku tokoh berupa: a) pembentukkan konsep diri perempuan, b) kemandirian perempuan, c) perjuangan kebebasan atas penentuan tubuh sendiri.

Kata kunci: gender, novel, perempuan berkalung sorban, feminisme 


\section{Pendahuluan}

Sastra merupakan bentuk refleksi kehidupan manusia yang dianggap sebagai imitasi perilaku manusia yang nyata. Adanya proses tiruan sosial dalam sebuah sastra tidak terlepas dari kehidupan pengarang itu sendiri sebagai bagian dari anggota masyarakat. Untuk itu, sebuah karya sastra merupakan bentuk komunikasi antara penulis dengan pembacanya (Siswanto, 2008). Hal yang dikomunikasikan pengarang adalah ide yang sering dipengaruhi oleh kehidupan nyata pengarang itu sendiri. Salah satu persoalan yang dilatari oleh persoalan di masyarakat, khususnya masyarakat Indonesia adalah ideologi patriarki. Patriarki merupakan sistem sosial yang menjadikan kekuasaa laki-laki berada di atas perempuan:

Patriarchy is a social system in which the role of the male as the primary authority figure is central to social organization, and where father hold authority over women, children and property. It implie the institution of male rule and privilege, and entails female subordination (Malti-Douglas, 2007)

Perempuan sebagai subordinat dalam ideologi patriarki dianggap sebagai bagian dari peraturan yang harus dipatuhi semua anggota masyarakat. Untuk itu, sistem patriarki bisa diterapkan di tingkat keluarga, masyarakat, atau negara di mana laki-laki mendominasi dalam semua hal seperti sumber daya manusia, ekonomi, politik, dan sosial. Segala aturan yang dipakai dalam sistem patriarki didasarkan pada kepentingan pihak laki-laki (Fayumi, 2001). Masyarakat patriarki menggunakan fakta tertentu mengenai fisiologi perempuan dan laki-laki sebagai dasar untuk membangun
Volume 3, Nomor 1, Januari 2021

ISSN 2655-3031 (P), 2655-7851 (O)

DOI: http://dx.doi.org/10.29300/disastra.v3i1.3559

serangkaian identitas dan perilaku maskulin dan feminim yang diberlakukan untuk memberdayakan laki-laki di satu sisi dan melemahkan perempuan di sisi lain. Masyarakat patriarki meyakinkan dirinya sendiri bahwa konstruksi budaya adalah alamiah sehingga normalitas seseorang bergantung pada kemampuannya untuk menunjukkan identitas dan perilaku gender. Perilaku tersebut secara kultural dihubungkan dengan jenis kelamin biologis seseorang. Masyarakat patriarki menggunakan peran gender yang kaku untuk memastikan perempuan tetap pasif dan laki-laki tetap aktif (Tong, 1998).

Indikator ideologi patriarki tergambar pada indikasi berikut, yaitu a) kekuasaan atau aturan dari garis bapak (patriarch) adalah sebuah sistem sosial di mana laki-laki mengontrol anggota keluarga, pemilikan, dan sumber ekonomi lainnya, serta sebagai pengambil keputusan bersama. b) Berbasis anggapan laki-laki lebih unggul dari perempuan sehingga perempuan yang merupakan bagian dari pemilikan laki-laki harus dikontrol dan diatur. c) Merupakan dasar kontrol, penindasan, serta eksploitasi perempuan di ranah publik dan privat.

Salah satu sistem yang meletakkan ideologi patriarki adalah gender yang mengakibatkan dampak ideologi ini semakin kuat dalam masyarakat. Bagi masyarakat di Indonesia, pemahaman tentang jenis kelamin sering dirancukan dengan fungsi dan peran, sehingga jenis kelamin tertentu akan bersinergi dengan fungsi dan peran tertentu. Pemahaman budaya ini mengakibatkan gender dapat diartikan sebagai perbedaan-perbedaan sifat, peranan, dan status antara laki-laki dan 
perempuan yang tidak berdasarkan biologis tetapi berdasarkan relasi sosial budaya yang dipengaruhi oleh struktur masyarakat yang lebih luas (Agustinus, 2007). Dalam pengertian identitas gender adalah defenisi seseorang tentang dirinya, khususnya dirinya sebagai perempuan dan berbagai karakteristik perilakunya yang dikembangkan sebagai hasil sosialisasi.

Gender diartikan sebagai harapanharapan budaya terhadap laki-laki dan perempuan (M.Lips, 2010). Gender lebih mendekatkan arti jenis kelamin dari sudut pandang sosial. Gender adalah behavioral differences antara laki-laki dan perempuan yang dikonstruksi secara sosial, yakni perbedaan yang bukan kodrat atau bahkan ciptaan Tuhan melainkan diciptakan oleh kaum laki-laki dan perempuan melalui proses sosial dan budaya yang panjang (Oakley, 1985). Perbedaan gender yang selanjutnya melahirkan peran gender sesungguhnya tidaklah menimbulkan masalah atau tidak perlu digugat (Caplan, 1987). Namun, mayoritas yang menjadi korban ketidakadilan gender adalah kaum perempuan, analisis gender menjadi alat gerakan feminisme untuk menjelaskan ketidakadilan (Fakih, 2001) .

Manifestasi ketidakadilan gender yang ditimbulkan oleh adanya asumsi sebagai berikut: a) terjadinya marginalisasi (kemiskinan ekonomi) terhadap kaum perempuan, b) terjadinya subordinasi pada salah satu jenis kelamin, yang umumnya pada kaum perempuan, c) pelabelan negative stereotype terhadap jenis kelamin tertentu, terutama kaum perempuan dan akibat anggapan itu terjadi diskriminasi serta berbagai ketidakadilan lainnya, d) kekerasan terhadap jenis kelamin tertentu,
Volume 3, Nomor 1, Januari 2021

ISSN 2655-3031 (P), 2655-7851 (O)

DOI: http://dx.doi.org/10.29300/disastra.v3i1.3559

umumnya perempuan karena perbedaan gender, e) peran gender perempuan adalah mengelola rumah tangga, banyak perempuan menanggung beban kerja domestik lebih banyak dan lebih lama.

Untuk lebih tajam memahami adanya ketidakadilan yang diakibatkan oleh ideologi patriarki dan pemahaman gender ini, maka dibutuhkan kajian yang lebih mendasar tentang hal tersebut. Kajian tersebut adalah gerakan feminisme yang merupakan sebuah kesadaran tentang ketakadilan yang sistematis bagi perempuan dalam berbagai sektor kehidupan serta tindakan-tindakan sadar oleh perempuan maupun laki-laki untuk mengubah keadaan tersebut (Bhasin \& Khan, 1995). Feminisme disebut juga sebagai gerakan perempuan yang menuntut persamaan hak sepenuhnya antara kaum laki-laki dan perempuan (Sigihastuti, 2002). Inti tujuan feminisme adalah meningkatkan kedudukan dan derajat perempuan agar sama atau sejajar dengan kedudukan dan derajat laki-laki (Djajanegara, 2000). Hal ini tentu bertentangan dengan ideologi patriarki dan gender. Untuk itu, feminisme adalah politik, sebuah politik langsung yang mengubah hubungan kekuatan kehidupan antara perempuan dan laki-laki dalam masyarakat. Kekuatan ini mencakup semua struktur kehidupan, keluarga, pendidikan, kebudayaan, dan kekuasaan. Segi-segi kehidupan ini menetapkan siapa, apa, dan untuk siapa serta akan menjadi apa perempuan itu (Sigihastuti, 2002). Secara prinsip, ia berakar pada posisi perempuan dalam dunia (filsafat, politik, ekonomi, budaya, sosial) patriarki dan beroientasi pada perubahan pola hubungan kekuasaan (Arimbi, 2007). 
Terdapat lima belas nilai-nilai dalam feminisme, yaitu: a) pengetahuan dan pengalaman personal, b) rumusan tentang diri sendiri, c) kekuasaan personal, d) otentitas, e) kreatifitas. f) sintetis, g) personal is political, h) kesetaraan, i) hubungan sosial timbal balik, j) kemandirian ekonomi, k) kebebasan seksual, 1) kebebasan reproduksi, n) perubahan sosial, dan o) berkekuatan politik dalam masyarakat. Nilai-nilai feminisme ini yang menjadi kajian penelitian yang akan dibahas dalam artikel ini (Arimbi, 2007).

Persoalan-persoalan perempuan dalam belenggu ideologi patriarki ini tergambar jelas dalam novel-novel di Indonesia. Kondisi ini tidak terlepas dari konteks patriarki yang melingkupi kehidupan masyarakat. Untuk itu, konteks ini semakin nyata keberadaannya dalam novel-novel baik dari pengarang dengan jenis kelamin laki-laki atau perempuan itu sendiri.

Seperti penelitian dengan judul Representasi Ideologi Patriarki dalam Novel Tanah Tabu: Kajian Feminisme Radikal. Novel Tanah Tabu karya Anindita $S$. Thayf mengungkapkan realitas yang terjadi pada masyarakat Papua, khususnya mengenai ideologi patriarki. Penelitian ini mendeskripsikan tentang representasi dan perlawanaan terhadap ideologi patriarki dengan menggunakan metode analisis deskriptif. Berdasarkan metode tersebut, representasi ideologi patriarki dalam novel Tanah Tabu mencakupi kekerasan, diskriminasi, dan subordinasi terhadap perempuan. Perlawanan yang dilakukan adalah dengan cara meninggalkan rumah dan dengan tidak menikah lagi (Farah, 2013).
Volume 3, Nomor 1, Januari 2021

ISSN 2655-3031 (P), 2655-7851 (O)

DOI: http://dx.doi.org/10.29300/disastra.v3i1.3559

Selain itu, terdapat juga penelitian tentang Inferioritas Tokoh Perempuan dalam Novel Bumi Cinta karya Habiburrahman El Shirazy. Dalam penelitian ini membahas tentang perempuan yang berada di posisi inferior. Posisi inferior yang dialami perempuan tidak hanya terjadi dalam dunia nyata. Dalam penelitian ini dapat diketahui penokohan perempuan dalam novel Bumi Cinta yang direpresentasikan pengarang. Inferioritas yang dialami tokoh perempuan. Kompensasi yang dilakukan tokoh perempuan serta kajian feminis pada tokoh perempuan (Alimatu'sadiah \& Nuryatim, n.d.)

Berdasarkan ketertarikan terhadap persoalan perempuan dalam novel yang berkaitan dengan adanya ideologi patriarki, maka perlu juga menggali lebih dalam mengenai hal tersebut dalam novel Perempuan Berkalung Sorban.

\section{Metode Penelitian}

Penelitian ini menggunakan pendekatan kualitatif dengan metode deskriptif analisis, yakni dengan cara mendeskripsikan fakta-fakta yang kemudian disusul dengan analisis yang tidak hanya menguraikan melainkan juga memberikan pemahaman dan penjelasan secukupnya. Tujuannnya adalah untuk mendeskripsikan dan menginterpretasikan ideologi patriarki secara sistematis, faktual, dan akurat mengenai fakta-fakta, sifat-sifat serta hubungan antarfenomena yang diselidiki. Untuk itu, dalam penelitian ini peneliti bertindak sebagai instrumen penelitian, perencana, pelaksana, pengumpul data, penganalisis, penafsir dan pelapor.

Data yang akan digali berupa kutipan-kutipan dalam bentuk kata, frasa, 
kalimat atau wacana yang mendeskripsikan dan menginterpretasikan. Dengan demikian, prosedur pengambilan data menggunakan tahapan, yaitu: 1) tahap pembacaan, 2) tahap pencatatan, 3) tahap pengelompokkan, 4) tahap penyortiran, 5) tahap pemaknaan. Sementara untuk prosedur analisis data menggunakan tahapan berikut ini. 1) Tahap reduksi data : Reduksi data mengrcu pada proses memilih, memfokuskan, dan menyederhanakan, meringkas, dan mengubah data mentah. 2) Tahap penyajian data, 3) Tahap penyimpulan : Menyimpulkan hasil temuan melalui kajian feminis berdasarkan data yang telah diuji kelogisannya, kekokohannya dan validitasnya.

\section{Hasil dan Pembahasan}

Perempuan Berkalung Sorban karya Abidah El Khalieqy merupakan karya sastra yang secara dominan mengisahkan penderitaan seorang perempuan yang bernama Annisa mulai dari kecil sampai dewasa. Penderitaan tersebut lahir dari aturan-aturan budaya yang membelenggu dengan berdasarkan pada pemahaman keagamaan yang keliru. Pemahaman tersebut didogmakan sebagai aturan Tuhan yang harus dipatuhi sebagai wujud perilaku keagamaan seorang perempuan. Ketidakadilan gender berada dalam tiga lingkaran, yaitu (1) lingkaran kekuasaan dari garis patriarki yang mengatur perempuan dari berbagai sisi, (2) lingkaran anggapan yang memandang perempuan kaum yang lemah sehingga berbagai akses untuk memperoleh kesetaraan tidak berfungsi, dan (3) lingkaran patriarki yang menjadi dasar untuk mengontrol, menindas dan mengeksploitasi perempuan di ranah
Volume 3, Nomor 1, Januari 2021

ISSN 2655-3031 (P), 2655-7851 (O)

DOI: http://dx.doi.org/10.29300/disastra.v3i1.3559

publik dan privat. Untuk itu, sikap feminisme dalam novel ini tergambar dalam perilaku tokoh berupa: a) pembentukkan konsep diri perempuan, b) kemandirian perempuan, c) perjuangan kebebasan atas penentuan tubuh sendiri.

\section{Lingkaran Kekuasaan atau Aturan dari} Garis Bapak (Patriarch)

Lingkaran kekuasaan atau aturan dari garis bapak (patriarch) adalah sebuah sistem sosial di mana laki-laki mengontrol anggota keluarga, pemilikan dan sumber ekonomi lainnya, serta sebagai pengambil keputusan bersama

Indikasi patriarki ini tergambar dalam pola pikir, tindakan, dan perilaku yang dialami Tokoh utama, yaitu Annisa mulai dari dia kecil.

\section{a. Aturan yang mengatur pilihan permainan perempuan sejak kecil}

Pilihan permainan anak perempuan telah diatur sesuai dengan jenis kelamin, apa yang pantas, tidak pantas bagi anak perempuan secara kaku diatur.

"O....jadi rupanya kamu yang punya inisiatif bocah wedhok. Kamu yang ngajari kakakmu jadi penyelam seperti ini? Kamu yang membujuk kakakmu jadi pengembara?"

"Ow....ow....ow...jadi begitu. Apa Ibu belum mengatakan padamu kalau naik kuda hanya pantas dipelajari oleh Kakakmu Rizal, atau Kakakmu Wildan, Kau tau mengapa? Sebab kau ini anak perempuan, Nisa. Nggak pantas, anak perempuan kok naik kuda, pencilakan, apalagi keluyuran mengelilingi ladang, sampai ke blumbang segala.Memalukan! Kau ini sudah besar masih bodoh juga, hehh!" Tasbih Bapak bergerak 
pelan, mengena kepalaku. (El Khalieqy, 2009: 6 dan 7)

b. Aturan yang mengatur perempuan bekerja di dapur

......Ruang bermainku mendapat pagar baru, lebih tinggi dan sempit untuk cakrawala penglihatannku. Tanganku mulai dilatih memegang piring,gelas, sendok, wajan dan apai pembakaran. Bau membuatku pusing dan tersedak bertubi-tubi. Bau bawang dan sambal terong membuatku bersin-bersin. Sampai lidahku tak pernah bisa menikmati sarapan pagi, bahkan tak juga merasakan kebebasan ketika kedua tangan ini mesti kembali mencuci piring yang dipenuhi minyak bekas makanan Rizal, Wildan dan Bapak yang terus saja duduk di meja makan sambil ngobrol dan berdahak. (El Khalieqy, 2009: 8-9)

c. Aturan yang mengatur kewajiban lakilaki dan perempuan berdasarkan jenis kelamin

“ Baiklah anak-anak." Pak Guru mencoba menguasai suasana, : dalam adat istiadat kita, dalam budata nenek moyang kita, seorang laki-laki memiliki kewajiban dan seorang perempuan juga memiliki kewajiban. Kewajiban seorang lakilaki mencari nafkah, baik di kantor, di sawah, di laut atau di mana saja asal bisa mendatangkan rezeki yang halal. Sedangkan seorang perempuan mereka juga memiliki kewajiban, yang terutama adalah mengurus urusan rumah tangga dan mendidik anak. Jadi memasak, mencuci, mengepel, menyetrika, menyapu, dan merapikan seluruh rumah adalah kewajiban seorang perempuan. Demikian juga memandikan, menyuapi,
Volume 3, Nomor 1, Januari 2021

ISSN 2655-3031 (P), 2655-7851 (O)

DOI: http://dx.doi.org/10.29300/disastra.v3i1.3559

menggantikan popok dan menyusui, itu juga kewajiban seorang perempuan. Sudah paham, anakanak....?" (El Khalieqy, 2009: 12)

d. Aturan yang mengatur jumlah jam bekerja perempuan lebih banyak dari laki-laki

"Coba Ibu jawab.Berapa jam seorang perempuan dapat menyelesaikan kewajibannya dalam sehari .Ayo?"

"Yang aneh apanya, Bu. Pak guru bilang kewajiban seorang perempuan itu banyak sekali, ada mencuci, memasak, menyetrika, mengepel, menyapu, menyuapi, menyusui, memandikan, dan banyak lagi. Tidak seperti laki-laki $\mathrm{Bu}$, kewajibannnya Cuma satu, pergi ke kantor. Mudah dihapalkan. Mengapa dulu aku tidak jadi laki-laki saja, Bu?” (El Khalieqy, 2009: 14)

\section{Lingkaran yang Berbasis Anggapan} Laki-Laki Lebih Unggul dari Perempuan

Lingkaran yang berbasis anggapan laki-laki lebih unggul dari perempuan sehingga perempuan yang merupakan bagian dari pemilikan laki-laki harus dikontrol dan diatur. Anggapan perempuan sebagai makhluk yang bodoh menjadi dasar bagi terlaksananya kekuasaan laki-laki terhadap perempuan. Laki-laki menganggap dirinya sebagai makluk yang lebih unggul daripaida perempuan, sehingga perempuan harus selalu diposisi kedua dalam segala hal. Dalam novel ini tercermin dalam sikapsikap berikut. 
a. Menganggap perempuan tidak memiliki argumen yang valid

Aku merenung sejenak. Kalau aku tak bisa menemukan jawabannya, dia pasti akan mengejekku. Mencibirku sebagai anak perempuan yang bodoh. (El Khalieqy, 2009:3)

b. Menyalahkan posisi perempuan saat ditimpa kesulitan

"Kamu lama sekali! Kalau saja terlambat sedetik, aku bisa mati.

Bodoh!”.( El Khalieqy, 2009:4)

"Dia yang mengajak, Pak,"Rizal mencari alasan dengan menunjukk mukaku. (El Khalieqy, 2009:6)

Begitulah.Ujung-ujungnya aku juga yang disalahkan.Padahal Rizal yang terlalu bernafsu dengan jaringnya. (El Khalieqy, 2009:8)

\section{c. Membatasi urusan perempuan}

"Jangan begitu, Nisa. Kita kan sedang bicara urusan laki-laki, “ tambah Wildan.

"Memangnya urusan laki-laki itu apa? Apa perempuan tak boleh mengetahuinya?" (El Khalieqy, 2009:10)

\section{d. Membatasi pendidikan perempuan}

"Tetapi anak perempuan kan tidak perlu sekolah tinggi-tinggi.Sudah cukup jika telah mengaji dan khatam. Sudah ikut sorogan kitab kuning..... (El Khalieqy, 2009:90)

Lingkaran yang Merupakan Dasar Kontrol, Penindasan, serta Eksploitasi Perempuan di Ranah Publik dan Privat

Ideologi patriarki yang ketiga ini memberikan pengaruh yang buruk bagi kehidupan perempuan karena ketidakadilan terhadap perempuan tdak hanya pada hak-
Volume 3, Nomor 1, Januari 2021

ISSN 2655-3031 (P), 2655-7851 (O)

DOI: http://dx.doi.org/10.29300/disastra.v3i1.3559

hak yang bersifat teknis tetapi hak yang mendasar, yaitu hak hidup.

\section{a. Mengontrol pilihan pendamping hidup seorang perempuan}

Terbayang kembali peristiwa pahit yang mengawali pernikahanku dengan Samsudin, laki-laki yang baru kulihat wajahnya hanya satu jam sebelum akad nikah dilaksanakan. Tubuhnya tinggi besar, dipenuhi gajih, dengan perawakan pegulat yang kehabisan nyali sesudah segalanya gagal. (El Khalieqy, 2009:104)

\section{b. Menindas hak kepemilikan tubuh}

....Dokter mengatakan bahwa aku nervous dan butuh istirahat. Tetapi Samsudin kurang bisa memahami kata-kata, apalagi kalimat panjang yang sederhana. Ia menjarah masa istirahatku dan kembali dengan tuntutannya. Ia sadar betul mengenai haknya sebagai suami terhadap istrinya.... (El Khalieqy, 2009:110)

\section{c. Menindas hak reproduksi perempuan}

"Kau memperkosaku, Samsudin!

Kau telah memperkosaku!"

"Memperkosa? Heh heh heh....,"ia terbahak-bahak kecil karena merasa puas mengerjaiku."Mana ada suami memperkosa istrinya sendiri. Kau ini aneh, Nisa......"

Dari paparan indikator ideologi patriarki di atas, tergambar kondisi tokoh utama yang terbelenggu oleh pemahaman budaya, baik dari keluarga, sekolah dan masyarakat. Kondisi ini menjadi hal yang biasa dan wajar apabila perempuan menganggap apa yang dialaminya sebagai bagian dari resiko hidup sebagai seorang 
LPJ D/SASTRRA

perempuan, seperti yang dipahami oleh Ibu Annisa.

Dari paparan di atas, telah jelas sikapsikap feminis yang ditunjukkan tokoh utama dalam novel ini yang semuanya menghasilkan perubahan dalam diri perempuan menjadi lebih baik. Sikap-sikap itu terefleksi dalam tiga hal yang menjadi alat perjuangan tokoh utama, yaitu Annisa.

\section{Pembentukkan Konsep Diri Perempuan}

Sikap-sikap Annisa dalam novel ini menggambarkan sebuah perjuangan feminisme yang menginginkan adanya kesadaran dalam diri perempuan untuk memahami konsep dirinya sendiri. Seperti nilai-nilai yang terkandung dalam feminisme, yaitu sebagai berikut.

\section{a. Kekuasaan Personal}

Kekuasaan personal menunjukkan bahwa perempuan berhak memutuskan pilihan hidupnya dalam bekerja, berorganisasi, berpakaian tertentu, tidak menikah, menikah,dll. Artinya apa yang dilakukan Annisa menunjukkan bahwa ia telah memiliki kesadaran kekuasaan personal, walaupun baru sebatas pada pola pikir. Namun, kekuasaan personal terhadap dirinya masih konsisten ia perjuangkan walaupun berada dalam kekuasaan suaminya yang otoriter. Bentuk kekuasaan personal itu tercermin dalam sikap seperti berikut: tetap memilih melanjutkan pendidikan walaupun ia pada awalnya jenjang pendidikannya hanya sampai tamat sekolah dasar, namun berkat kegigihan kekuasaan personalnya ia mampu melanjutkan sampai jenjang perguruan tinggi.
Volume 3, Nomor 1, Januari 2021

ISSN 2655-3031 (P), 2655-7851 (O)

DOI: http://dx.doi.org/10.29300/disastra.v3i1.3559

\section{b. Rumusan tentang Diri Sendiri}

Rumusan tentang diri sendiri menunjukkan bahwa seorang perempuan berhak merumuskan dirinya sendiri. Artinya, Annisa telah merumuskan konsep bagaimana seorang perempuan harus meletakkan dirinya dalam interaksi di masyarakat. Konsep diri ini tidak mengikuti alur yang telah ada dan berkembang secara budaya. Namun konsep diri ini dikembangkan berdasarkan nilai-nilai kemanusiaan yang tidak hanya berlaku untuk laki-laki saja tetapi juga dapat berlaku untuk perempuan. Konsep diri bahwa perempuan itu tidak berbeda dengan lakilaki, perempuan harus menentukan pilihannya sendiri, perempuan dapat mandiri tanpa tergantung dengan laki-laki, perempuan dapat melanjutkan jenjang pendidikan sesuai dengan kemampuan dirinya sendiri, perempuan dapat menentukan kepemilikan atas tubuhnya, sehingga perempuan tidak lagi menjadi objek seksualitas tetapi sebagai subjek seks.

\section{c. Kesetaraan}

Konsep diri yang utama dapat dikembangkan melalui prinsip kesetaraan. Feminisme mengandung nilai bahwa kesetaraan hak antara laki-laki dan perempuan adalah substansi kemanusiaan, yang akan mengarahkan kehidupan yang adil antara laki-laki dan perempuan. Kesetaraan juga menjadi bagian dari rasionalisasi kemajuan masyarakat, baik laki-laki maupun perempuan. Sebagai substansi kemanusiaan, kesetaraan ini harus dikembangkan sejak kecil atau sedari dini. Seperti pilhan-pilihan permainan menunjukkan adanya kesetaraan sejak kecil. Hal ini juga yang diperjuangkan oleh 
Annisa sejak ia kecil. Sejak ia menolak Ayahnya melarang ia naik kuda dan tetap ia secara diam-diam belajar naik kuda, hal tersebut telah menggambarkan bagaimana tokoh Annisa menuntut kesetaraan antara ia dan kakak laki-lakinya. Kesetaraan itu juga tergambar dari sikap Annisa yang menolak untuk bekerja di dapur yang dianggap sebagai kewajiban dari perempuan serta keinginannya untuk bekerja di kantor yang dianggap merupakan wilayah kerja laki-laki. Konsep diri kesetaraan ini menunjukkan bahwa Annisa memang telah memiliki konsep diri yang berbeda dengan perempuan lain dalam novel tersebut. Melalui kesetaraan ini, Annisa mengembangkan konsep dirinya secara matang dan baik.

\section{d. Personal is Political}

Feminisme menekankan basis psikologis penindasan patriarki. Frase ini menciptakan hubungan langsung antara solidaritas dan subjektivitas sehingga memahami politik situasi perempuan berarti memahami kehidupan pribadi perempuan. Konsep diri dalam novel ini juga diwujudkan dalan siruasi personal is political. Situasi tersebut digambarkan dalam hubungan personal Annisa dengan istri kedua Samsudin yang merupakan madunya dalam cerita tersebut, yaitu Mbak Kalsum. Mbak Kalsum dalam cerita tersebut digambarkan sebagai perempuan dengan nasib yang sama dialami oleh Annisa, yang penderitaan tersebut bersumber dari Samsudin, suami mereka bersama. Keduanya membangun komunikasi dan kekuatan bersama sehingga timbul rasa solidaritas dan subjekivitas. Adanya rasa solidaritas dan subjektivitas ini membuat mereka dapat memahami situasi masing-
Volume 3, Nomor 1, Januari 2021

ISSN 2655-3031 (P), 2655-7851 (O)

DOI: http://dx.doi.org/10.29300/disastra.v3i1.3559

masing, sehingga akhirnya mbak Kalsum juga yang memberikan kesaksian pada sidang perceraian Annisa dan Samsudin.

\section{e. Kemandirian Perempuan}

Tokoh Annisa yang pendidikannya hanya sampai pada tingkat sekolah dasar, ternyata akhirnya dapat menyelesaikan pendidikan sampai perguruan tinggi. Proses pendidikan tersebut dicapainya dalam ia menempuh perkawinannya dengan Samsudin yang penuh dengan penderitaan. Sikap-sikap kemandirian ini tergambar dalam prinsip berikut.

1) Identifikasi Diri pada Perempuan

Hal ini berarti keyakinan perempuan terhadap individualitas dan potensi serta persepsi mengenai dirinya sebagai anggota komunitas perempuan sehingga melahirkan identifikasi diri yang ditentukan oleh perempuan sendiri. Identifikasi diri tercermin dalam cerita ini berbentuk sikapsikap Annisa yang merefleksikan kesadarannya sebagai perempuan yang mandiri. Kemandirian tersebut tampak pada prinsip-prinsip hidup yang diyakininya sebagai sebuah kebenaran. Walaupun sistem patriarki telah berhasil meletakkannya pada penderitaan akibat perkawinan yang dipaksakan oleh keluarga, namun Annisa tetap dapat melanjutkan kehidupannya dengan prinsip-prinsip hidup yang diyakininya. Prinsip-prinsip hidup itulah yang berhasil membawa Annisa pada kesuksesan hidupnya sebagai perempuan yang mandiri. Melalui perjuangannya dalam meraih pendidikan yang tinggi menjadikan Annisa dapat hidup mandiri tanpa tergantung pada siapapun. 
2) Hubungan Sosial Timbal Balik

Persoalan ketertindasan perempuan dapat dilihat dari apakah hubungan sosial timbal balik antara laki-laki dan perempuan telah setara. Dalam cerita ini, hubungan tersebut tercermin dalam interaksinya dengan lek Khudori sebagai paman yang selalu mendampingi Annisa. Kesetaraan hubungan dengan Lek Khudori terbentuk dari sikap-sikap Annisa yang telah berhasil menciptakan hubungan yang harmonis tanpa membedakan jenis kelamin. Hubungan ini tercipta melalui komunikasi yang selalu mengedepankan nilai-nilai kemanusiaan yang sesuai dengan hak dan kewajibannya. Walaupun Lek Khudori dan Annisa memiliki jarak usia yang jauh, namun keduanya telah berhasil saling membagi ilmu dan mentransfer pengetahuan sehingga dalam diri Annisa dapat terbentuk sikapsikap yang membedakannya dengan perempuan secara umum. Kesetaraan hubungan ini juga semakin terbentuk dalam diri mereka hingga keduanya diikat dalam perkawinan.

\section{f. Perjuangan Atas Kebebasan Penentuan Tubuh Sendiri}

Harga diri dan kehormatan perempuan terletak bagaimana perempuan itu sendiri menghargai dan menghormati tubuhnya sebagai bagian dari martabat perempuan. Kebebasan penentuan tubuh sendiri dalam kajian feminisme berkaitan dengan hal-hal berikut.

\section{1) Kebebasan Seksual}

Perempuan perlu mendefenisikan sendiri sebagai subjek seksual bukan objek seksual. Dalam novel ini, tokoh Annisa secara gigih mempertahankan prinsipprinsip bahwa perempuan bukan sebagai
Volume 3, Nomor 1, Januari 2021

ISSN 2655-3031 (P), 2655-7851 (O)

DOI: http://dx.doi.org/10.29300/disastra.v3i1.3559

objek seksual. Walaupun tetap dilakukannya dengan terpaksa ketika suaminya meminta haknya sebagai seorang suami, hal tersebut dilakukan semata-mata melaksanakan kewajibannya sebagai istri. Dengan prinsipnya, ia tetap menuntut suaminya memperlakukan dirinya dengan sebaiksebaiknya.

\section{2) Kebebasan Reproduksi}

Ada dua gagasan yang mendukung pandangan feminisme mengenai kebebasan reproduksi: (1) gagasan penentuan atas tubuh sendiri, dan (2) gagasan bahwa kesadaran reproduksi merupakan hal yang terus berlangsung dan integratif, secara terus-menerus menegaskan kesatuan perempuan dengan alam dan siklus waktu. Kebebasan reproduksi dalam cerita ini benar-benar menggambarkan bahwa perempuan memiliki hak atas reproduksi yang ia miliki. Tokoh Annisa digambarkan sebagai perempuan yang dengan prinsipnya menganggap bahwa perempuan memiliki hak atas tubuh dan reproduksinya sendiri, sehingga keputusan untuk melakukan hubungan suami istri bukan keputusan sepihak hanya dari laki-laki saja, tetapi juga keputusan perempuan. Perempuan bukan objek dari seksualitas laki-laki, sehingga tubuh perempuan hanya menjadi pelampiasan saja. Dengan perjuangan kebebasan reproduksi ini Annisa menunjukkan bahwa perempuan berhak atas tubuhnya sendiri.

\section{Simpulan}

Abidah El Khalieqy dalam novel Perempuan Berkalung Sorban ingin menyampaikan tentang pentingnya seorang perempuan memahami konsep dirinya. 
Konsep diri perempuan ini tidak berdasarkan pada perbedaan jenis kelamin, namun pada hak-hak perempuan sebagai manusia. Upaya memanusiakan perempuan dalam novel ini terjadi secara lembut dan tidak frontal. Perempuan tidak bisa dengan dirinya sendiri menentang pemahaman budaya yang berlandaskan pada pemahaman agama yang keliru. Perlu perjuangan untuk menyamakan persepsi tentang keberadaan perempuan dalam keluarga dan masyarakat.

Abidah El Khalieqy secara halus membangun konsep bahwa perempuan dapat diterima konsep dirinya melalui pendidikan. Pendidikanlah yang mengubah persepsi masyarakat tentang eksistensi perempuan. Pilihan-pilihan yang diciptakan perempuan akan menjadi alternatif bagi dirinya apabila ia sendiri yang menciptakan alternatif tersebut. Pemahaman budaya tentang perempuan adalah salah satu alternatif yang diciptakan masyarakat dan perempuan yang cerdas harus menciptakan alternatif lain yang sesuai dengan potensi dirinya.

Kebebasan penentuan hak atas tubuh sendiri juga menjadi isu penting yang ingin dibahas oleh Abidah El Khlieqy. Selama ini perempuan menerima semua perlakuan lakilaki atas tubuh mereka tanpa memiliki pandangan lain bahwa mereka berhak atas keputusan tentang hak-hak atas tubuh dan reproduksi. Perlu komunikasi yang terbuka untuk menciptakan kondisi penghormatan terhadap hak atas tubuh dan reproduksi perempuan ini. Komunikasi ini akan tercipta dengan baik apabila telah terjalin kesetaraan antara laki-laki dan perempuan.
Volume 3, Nomor 1, Januari 2021

ISSN 2655-3031 (P), 2655-7851 (O)

DOI: http://dx.doi.org/10.29300/disastra.v3i1.3559

\section{Daftar Pustaka}

Agustinus, L. (2007). Perihal Ilmu Politik: Sebuah Bahasan Memahami Ilmu Politik. Yogyakarta: Graha.

Alimatu'sadiah, \& Nuryatim, A. (n.d.). Inferioritas Tokoh Perempuan dalam Novel Bumi Cinta. Seloka: Jurnal Pendidikan Bahasa Dan Sastra Indonesia. Retrieved from http://journal.unnes.ac.id/sju.index.php/ seloka

Arimbi, H. (2007). Percakapan tentang Feminisme VS Neoliberalisme. Jakarta: Debt Watch Indonesia.

Bhasin, K., \& Khan. (1995). Feminisme dan Relevansinya. Jakarta: Gramedia.

Caplan, P. (1987). The Cultural Construction of Sexuality. London: Routledge.

Djajanegara, S. (2000). Kritik Sastra: Sebuah Pengantar. Jakarta: Gramedia.

Fakih, M. (2001). Sesat Pikir Teori Pembangunan dan Globalisasi. Yogyakarta: Pustaka Pelajar.

Farah, D. dkk. (2013). Refresentasi Ideologi Patriarki dalam Novel Tanah Tabu Kajian Feminisme Radikal. Jurnal Sastra Indonesia, 2. Retrieved from http://journal.unnes.ac.id/sju.index.php/ jsi

Fayumi, B. (2001). Keadilan dan Kesetaraan Gender (perspektif Islam). Jakarta: Tim Pemberdayaan Perempuan Bidang Agama DEPAG RI.

M.Lips, H. (2010). Sex and Gender: An Introduction. Radford University: Radford VA.

Malti-Douglas, F. (2007). Encylopedia of Sex and Gender. Detroit: Macmillan. 
Retrieved from http://en.wikipedia.org/wiki/patriarcgy.

Moelino dalam Sugihastuti dan Suharto.2001. Teori dan Apresiasi sastra, Yogyakarta: Pustaka Pelajar.

Oakley. (1985). Sex, Gender, anda Society. London: Templesmith Repointed with New Introduction: Gower.

Sigihastuti. (2002). Kajian sastra Feminis Teori dan aplikasinya. Yogyakarta: Pustaka Pelajar.

Siswanto, W. (2008). Pengantar teori Sastra. Jakarta: Grasindo.

Tong, R. P. (1998). Feminist Thoight:Pengantar Paling Komprehensif Kepada Aliran Utama Pemikiran Feminis. Yogyakarta: Jalasuta. 